through the Korean War. After the war he was appointed instructor in the department of law at the United States Military Academy at West Point. He received his masters of law degree from New York University at this time.

Dr. Nelson received his masters of arts degree from Miami University while he continued serving the nation in the Air Force. Dr. Nelson served as deputy for administration, deputy department head, and associate professor in the department of political science at the United States Air Force Academy. During this time he completed his Ph.D. in American studies. He retired from the Air Force in 1969 after 27 years of service and numerous decorations and awards including the Distinguished Flying Cross and World War II Victory Medal.

After his retirement Dr. Nelson accepted the position of chair and professor in the department of political science at Memphis State University from 1969-73. In 1973 Dr. Nelson joined James Madison University in Harrisonburg, Virginia, as vice president and provost for academic affairs. He also served as head of the department of political science until his retirement in 1992. Dr. Nelson taught constitutional law, civil rights, and a seminar in international terrorism. He was the author of numerous articles in professional journals and two books: American Government and Political Change and The Politics of Science. After his retirement Dr. Nelson served as professor emeritus at James Madison University. The William R. Nelson Institute for International and Public Affairs at James Madison University was created in his honor by chancellor emeritus Dr. Ronald E. Carrier.

Dr. Nelson is survived by his wife Dr. Eileen Schmitt Nelson, professor emeritus, psychology department, James Madison University; sons R. Ryan Nelson of Charlottesville, VA, Edward R. Farnen of Cumming, GA, Carlton Nelson of Baltimore, MD, and Stuart Nelson of Salt Lake City, UT; daughters Pamela S. Nelson of Richmond, VA, Nancy Sarco of Harrisonburg, VA, Tina Hair of Murray, UT, Camille Strasters and St. Claire Nelson both of Salt Lake City, UT, and Sarah Stokke-Johnson of Oslow, Norway; and numerous grandchildren and great-grandchildren. He was preceded in death by a daughter Judy Pepper of Salina, KS.

Memorial contributions may be sent to the William R. Nelson Institute for International and Public Affairs, James Madison University, Moody Hall, MSC 1205, 800 S. Main Street, Harrisonburg, VA 22807, or Community Caregivers Network, James Madison University, Blue
Ridge Hall, MSC 9014, 800 S. Main

Street, Harrisonburg, VA 22807.

Anthony J. Eksterowicz James Madison University

\section{Morris S. Ogul}

Morris S. Ogul died on April 6, 2008, after a lengthy illness finally succumbing to pneumonia. He was 76. After receiving his Ph.D. from the University of Michigan, Morry spent his entire career on the faculty of the political science department at the University of Pittsburgh, beginning in 1957 and became professor emeritus in 1998. He also served as chair of the department.

Born in Detroit on April 15, 1931, Morry received his BA from Wayne State University. He moonlighted then as a taxi driver. This aspect of Morry's biography assumed importance for colleagues and friends who were first-time passengers in his car and who were otherwise comforted by Morry's mild manners, caution, and meticulousness. Once behind the wheel of his car, however, they saw a different side of this very gentle and humble man as he drove with abandon through alleyways and back roads with the instincts of the taxi driver he had been.

I had the good fortune to have known Morry Ogul from a number of perspectives - as a student, a colleague for nearly 30 years, and a friend. He was an extraordinary teacher and mentor, a wonderful colleague, a terrific kibitzer and source of advice, and a valued friend. We traveled along related scholarly pathways that gave us much to talk about, and because of that we also found an opportunity to collaborate.

Morry's signature work Congress Oversees the Bureaucracy: Studies in Legislative Supervision pioneered in a systematic way the now flourishing literature on legislative oversight of the bureaucracy. His work was carefully crafted, wise in the ways of Congress, and the product of astute observation.

Morry also collaborated with another Pitt colleague, Bill Keefe, to produce a textbook on the legislative process - not merely Congress-The American Legislative Process: Congress and the States that had gone into 10 editions. It was noted by one reviewer of the book that it was an inconceivable idea brilliantly executed. Another quite remarkable aspect of the book was the partnership of the two authors - a kind of political science odd couple. Bill Keefe was the Oscar Madison of this duo; Morry Ogul, the Felix Unger. Bill's office (like mine) had generations of paper lying on his desk.
Morry kept a can of EndDust nearby and only the day's business was to be found on his desk. His office was pristine and his style, if it could be called that, was utterly meticulous, precise, and understated.

Despite his quiet and unassuming ways, Morry Ogul was a major presence in the political science department at Pitt during his lengthy tenure there. He was a dedicated teacher at both the undergraduate and graduate levels. More than a teacher, he was a mentor to undergraduates and graduates alike. As one former graduate student put it, "Morry was like Mr. Rogers goes to political science." One of his former undergraduate students said of him that in the classroom, he "challenged students to question themselves and to look at problems from different angles and to always dig deeper." But he did this "in a very gentle and respectful way making students feel they had contributed something important to the discussion or made a very insightful comment. He would then turn the comment into something much better and then give the student full credit and thank him or her."

Although Morry had a gentle and unassuming personal style, he had an incisive and analytic mind and an inner core of steel. He was a kind man but an unsentimental one. His classes were places where fashionable but vacuous ideas came to die. He insisted on disciplined and rigorous thinking but in a manner that students might better understand how to bring these tools to their own cognitive processes. Morry strived to have students understand political analysis and why it is that people and groups have different interests. He was committed to political analysis so as to enable students to understand the presence and legitimacy of political conflict and the natural diversity of interests in a pluralistic and representative political order. As part of his pedagogical credo, the classroom was never to be used to mount a soap box. He was dispassionate without being detached. In 1985, Morry was the recipient of a Chancellor's Distinguished Teaching Award. This award was especially gratifying because it demonstrated that a purposefully anti-charismatic professor could be recognized for the quality of his teaching. And like most professors, Morry could not stop teaching even while he was in ill health. His caretaker commented that she learned a lot about government from him.

As department chair, Morry took his duties very seriously but executed them with equanimity. He was superb at finding people's comfort zones, at the critical role of keeping confidences, at calming 
the nerves of those with high anxiety, and at subtly deflating those with egos beyond their accomplishments. He was calm, competent, and civilized.

In the days before e-mail and text messaging when people actually had to talk to one another, Morry was the go-to colleague for everything from professional interests and advice to consumer decisions. When you wanted the lowdown on what-to-buy or not-to-buy, Morry had researched the matter every which way. He was Consumer Reports without the subscription fee. This was not an easy matter in pre-Internet days. Of course, Morry's research on consumables, however thoroughly performed, was not always infallible. A colleague who had placed great faith in Morry's "consumer reports" and who was in the market for a car followed his seemingly authoritative advice every step of the way and purchased the car that Morry recommended. He came to conclude that it was the worst consumer mistake he had ever made. Morry probably would have drawn the conclusion that all expectations must be empirically tested.

Morry saw through pretense and malarkey more than most of us. He was skeptical of self-advertisers and catch phrases. He delighted in puncturing holes in PR flack and advertisingwhether in academia or the commercial world. He was fond of sending up the advertisement of a now long defunct, if improbably named, discount appliance store in Pittsburgh, Kelly and Cohen, which claimed that "we lose money on every sale but make up for it in volume." Morry was dedicated to the proposition that not only should we not fall for that line in our purchases but we also should be skeptical of its equivalents in politics.

Morry was both an intensely private person yet very sociable. He enjoyed interacting with colleagues, friends, and students. He never advertised his many merits or wished to have them advertised by others on his behalf. He was a throwback to the days before academic brag sheets came into style. Even in death, Morry wished to have no funeral or memorial services. The departmental colleagues, former students, and others from Pitt who had known Morry well during his career dutifully disobeyed his desire to have nothing said of him. Fortunately, two of Morry's colleagues at Pitt, Jon Hurwitz and Ronald Linden, thought it best to organize a remembrance event on April 28 that, like Morry himself, was full of kindness, humor, and dignity. One of Morry's nieces observed that he was "a modest man" who "would never toot his own horn." It was, none- theless, comforting to those of us who knew and appreciated him to toot it for him knowing full well that he would have disapproved.

Morry was predeceased by his wife, Eleanor. He leaves behind two nephews and two nieces and three grand-nephews and two grand-nieces. Contributions may be made in Morris Ogul's memory to the Dr. Morris S. \& Eleanor S. Ogul Fund c/o The University of Pittsburgh, Office of Institutional Advancement, 200 South Craig Street, 500 Craig Hall, Pittsburgh, PA 15260.

Bert A. Rockman
Purdue University

\section{James S. Pacy}

It is with great sadness that we report the death of James S. Pacy, professor emeritus of political science. Jim died at his home in Burlington, Vermont, on April 21, 2008, of complications from Alzheimer's disease at the age of 77 . Jim, of proud Hungarian descent, was born in Caledonia, Ontario, on August 17,1930 . His family emigrated to Manville, New Jersey, when he was two years old. Manville, at the time the company town of asbestos manufacturer Johns-Manville, was an ethnically diverse community just a short drive up from Princeton but in an entirely different world. His hometown was the topic of many a reminiscence and story told by Jim over the years. Manville, for Jim, was always a reminder of the importance of home, ethnic ties, and community. For him, that humble background would lead to greater things.

In 1952, Jim earned his undergraduate degree in history from Lebanon Valley College. He also earned an MA degree in history from the University of Missouri in 1956. But his love was political science and international relations, which culminated in his Ph.D. at American University in 1969, where he also received the Pitman Potter Medal in International Law. During his graduate years, he received a fellowship at Harvard University, where he studied under Prof. Hans Morgenthau of the University of Chicago, the leading scholar of realism in international relations.

Jim was a veteran of our armed services. From 1952-1956, he served in a variety of military capacities, especially at the U.S. Air Force "filter center" in Fargo, North Dakota. His chief assignment was to tour the region, training civilians in the identification of Soviet aircraft. Such was his prowess on the job that not a single Russian plane ever penetrated North Dakota airspace. More im- portantly, North Dakota was the home of his future wife, Ruth West Pacy. In 1956, after his discharge, Jim volunteered for service as an interpreter in processing Hungarian refugees at Camp Kilmer, New Jersey.

Starting in 1957, Jim worked in Washington, D.C., first at the National Federation of Wildlife, where he was co-editor of The Conservation Directory, then at the Special Operations Research Office (SORO) at American University, directed by the esteemed Prof. Harold Gosnell, one of the pioneering scholars of the Chicago school of behavioralism.

Through those years, Jim pursued his graduate studies while supporting his young family.

In 1965, Jim joined the faculty of Westminster College, in Fulton, Missouri, where his reputation as a skilled teacher quickly grew. Westminster was the site of Winston Churchill's famous "iron curtain" speech in 1946; for his part, Jim was a lifelong member of the Churchill Society. On a lark at an annual meeting of the APSA, Jim responded to a job posting by the University of Vermont. He met with two faculty members-professors Raul Hilberg, the noted Holocaust scholar, and Jay Gould-who urged his immediate hiring. From 1967 on, UVM would be his home until his retirement in 1993.

At UVM, Jim Pacy proved to be a hire of very great merit. As at Westminster, he quickly established a reputation as one of the best teachers on campus. His classes on international relations, diplomacy, and international organization were always in great demand. A small testament: his class on international organization was always over-subscribed and regularly filled the largest lecture halls on campus. In the summer of 1976, as the Montreal Olympics were underway, he offered his students a special treat: a course called "Politics and International Sports." Jim was beloved by his students, entertained them in his home, and kept in contact with many of them over the years. He served as the faculty adviser to the Warren R. Austin Model United Nations Club, as UVM's Foreign Service adviser, and as campus coordinator of the State Department's Diplomatin-Residence program. A strong supporter of the UVM men's hockey team and a season ticketholder, Jim served as chair of the university's Athletic Council and as faculty NCAA representative. In 1985, he was honored by UVM with the George V. Kidder Award. The Kidder Award is the highest faculty honor on campus, determined by distinguished service to the university by vote of the alumni association. 